\title{
Hydrogen-driven asymmetric reduction of hydroxyacetone to $(R)-1,2$-propanediol by Ralstonia eutropha transformant expressing alcohol dehydrogenase from Kluyveromyces lactis
}

Takahiro Oda', Koji Oda' ${ }^{1}$, Hiroaki Yamamoto², Akinobu Matsuyama², Masaharu Ishii ${ }^{3}$, Yasuo Igarashi ${ }^{3}$ and Hirofumi Nishihara ${ }^{1 *}$

\begin{abstract}
Background: Conversion of industrial processes to more nature-friendly modes is a crucial subject for achieving sustainable development. Utilization of hydrogen-oxidation reactions by hydrogenase as a driving force of bioprocess reaction can be an environmentally ideal method because the reaction creates no pollutants. We expressed NAD-dependent alcohol dehydrogenase from Kluyveromyces lactis in a hydrogen-oxidizing bacterium: Ralstonia eutropha. This is the first report of hydrogen-driven in vivo coupling reaction of the alcohol dehydrogenase and indigenous soluble NAD-reducing hydrogenase. Asymmetric reduction of hydroxyacetone to (R)-1,2-propanediol, which is a commercial building block for antibacterial agents, was performed using the transformant as the microbial cell catalyst.

Results: The two enzymes coupled in vitro in vials without a marked decrease of reactivity during the $20 \mathrm{hr}$ reaction because of the hydrogenase reaction, which generates no by-product that affects enzymes. Alcohol dehydrogenase was expressed functionally in $R$. eutropha in an activity level equivalent to that of indigenous NAD-reducing hydrogenase under the hydrogenase promoter. The hydrogen-driven in vivo coupling reaction proceeded only by the transformant cell without exogenous addition of a cofactor. The decrease of reaction velocity at higher concentration of hydroxyacetone was markedly reduced by application of an in vivo coupling system. Production of (R)-1,2-propanediol (99.8\% e.e.) reached $67.7 \mathrm{~g} / \mathrm{l}$ in $76 \mathrm{hr}$ with almost a constant rate using a jar fermenter. The reaction velocity under $10 \% \mathrm{P}_{\mathrm{H} 2}$ was almost equivalent to that under $100 \%$ hydrogen, indicating the availability of crude hydrogen gas from various sources. The in vivo coupling system enabled cell-recycling as catalysts.
\end{abstract}

Conclusions: Asymmetric reduction of hydroxyacetone by a coupling reaction of the two enzymes continued in both in vitro and in vivo systems in the presence of hydrogen. The in vivo reaction system using $R$. eutropha transformant expressing heterologous alcohol dehydrogenase showed advantages for practical usage relative to the in vitro coupling system. The results suggest a hopeful perspective of the hydrogen-driven bioprocess as an environmentally outstanding method to achieve industrial green innovation. Hydrogen-oxidizing bacteria can be useful hosts for the development of hydrogen-driven microbial cell factories.

Keywords: Hydrogen-driven bioconversion, Hydrogen-driven cell factory, NAD-reducing soluble hydrogenase, Alcohol dehydrogenase, Cofactor regeneration, (R)-1,2-propanediol, Hydrogen-oxidizing bacterium, Ralstonia eutropha

\footnotetext{
* Correspondence: hiro@mx.ibaraki.ac.jp

${ }^{1}$ Department of Bioresource Science, College of Agriculture, Ibaraki

University, 3-21-1 Chu-ou, Ami-machi, Inashiki-gun, Ibaraki 300-0393, Japan

Full list of author information is available at the end of the article
} 


\section{Background}

The importance of bioprocess reactions that work effectively under mild conditions is growing rapidly as increasing demand for green innovation of industrial process. The conversion of a ketone to a corresponding alcohol represents a common redox-reaction in organic chemistry $[1,2]$. Dehydrogenases and reductases are promising biocatalysts for such reactions, of which the vast majority require nicotinamide cofactors such as NADH and NADPH as reductant. Given the costs of these cofactors, their stoichiometric use is economically infeasible. Therefore, various in situ regeneration methods including chemical, photochemical, electrochemical, and enzymatic reactions have been investigated [1-5]. Enzymatic approaches are particularly attractive for industrial process because of their high selectivity and efficiency. For example, a bioreduction system for the production of chiral alcohols has been reported using an Escherichia coli transformant, in which $\mathrm{NAD}(\mathrm{P}) \mathrm{H}-$ dependent carbonyl reductase and glucose dehydrogenase were heterologously co-expressed [1]. Continuous production of chiral alcohol was achieved through the in vivo coupling reaction of these enzymes, but production of equimolar amounts of a waste product, gluconate, is problematic. Formate dehydrogenase is known as another useful enzyme for cofactor regeneration [3], the benefits of which include its use of formate as an inexpensive substrate for cofactor reduction and generation of gaseous $\mathrm{CO}_{2}$ as the only by-product. It does not affect activities of the enzymes and it is easily separated. However, generation of $\mathrm{CO}_{2}$ is problematic in global warming issues. The low catalytic activity of formate dehydrogenase is also cited as an important shortcoming.

Hydrogen, a strong, inexpensive reductant, is also innocuous to the enzymes which will be coupled to a hydrogenase reaction for production of objective products. Importantly, oxidation of hydrogen by hydrogenase causes no pollution. Therefore, a hydrogen-driven bioconversion system can present an environmentally ideal method. The NAD-reducing soluble hydrogenase (ReSH) from Ralstonia eutropha (formerly Alcaligenes eutrophus), which is classified in Group 3 of [NiFe]-hydrogenase [6], is promising for such biocatalytic application as the enzyme is notably oxygen-tolerant $[7,8]$. Several reports have described that an in vitro coupling reaction by $\mathrm{ReSH}$ and NADdependent dehydrogenases functions effectively [9-11]. Permeabilized cells of $R$. eutropha were also evaluated as whole-cell coenzyme regeneration catalysts in an organicaqueous two-phase system, in which reduction of cyclohexanone was examined using in vitro coupling reaction of a commercial horse-liver alcohol dehydrogenase and permeabilized $R$. eutropha cells [12]. The coupling reaction by two permeabilized cells, $R$. eutropha and Gluconobacter oxydans, has also been examined for reduction of 2-octanone to produce (S)-2-octanol using $\mathrm{H}_{2}$ as reductant [13]. The NADP-reducing hydrogenase I from Pyrococcus furiosus has also been coupled with Thermoanaerobium sp. alcohol dehydrogenase in vitro for reduction of acetophenone and (2S)-hydroxy-1-phenylpropanone, which have been converted to corresponding chiral alcohols with total turnover numbers (mol product/mol consumed cofactor) of 100 and 160, respectively [14]. However, the in vivo coupling reaction performed in E. coli cells [1], which must be more advantageous as a practical system, has not been reported to date.

In this study, we expressed alcohol dehydrogenase (KlADH) from Kluyveromyces lactis [15] in R. eutropha cells and evaluated the in vivo coupling reaction of $\mathrm{ReSH}$ and KlADH (Figure 1). Asymmetric reduction of hydroxyacetone to $(R)$-1,2-propanediol, which is used as a commercial building block for synthesis of antibacterial agents, was examined using the transformant cells as $\mathrm{H}_{2}$ driven microbial catalysts in the presence of hydrogen.

\section{Results and discussion}

\section{$\mathrm{H}_{2}$-driven reduction of hydroxyacetone by in vitro} enzymatic coupling of ReSH and KIADH

To confirm the coupling reaction of $\mathrm{ReSH}$ and $\mathrm{KlADH}$ in vitro, reduction of hydroxyacetone was performed in $1 \mathrm{ml}$ of reaction mixture containing $0.2 \mathrm{U}$ of each enzyme solution and $1 \mu \mathrm{mol}$ of $\mathrm{NADH}(1 \mathrm{mM})$ in vials under $\mathrm{H}_{2}$ atmosphere. When $2 \%(\mathrm{v} / \mathrm{v}, 294 \mu \mathrm{mol}$ in the reaction mixture) of hydroxyacetone was subjected for the reaction, $235-252 \mu \mathrm{mol}$ of the substrate was reduced to 1,2-propanediol in $20 \mathrm{hr}$. Reduction of $240 \mu \mathrm{mol}$ of substrate is expected by the $0.2 \mathrm{U}$ of each enzyme activity in $20 \mathrm{hr}$, indicating that the coupling reaction proceeded effectively without a marked decrease of either $\mathrm{ReSH}$ or KlADH activity during the period. This result is attributable to the characteristic of hydrogenase responsible for $\mathrm{NADH}$ regeneration, which creates no byproduct affecting the enzyme performance. The product was reduced to $134-158 \mu \mathrm{mol}(55.8-65.8 \%$ of the expected amount; $240 \mu \mathrm{mol})$ when the initial concentration of hydroxyacetone was increased to $3 \%(\mathrm{v} / \mathrm{v})$.

\section{Heterologous expression of KIADH in R. eutropha $\mathrm{H} 16$}

We consider that it is important to express KlADH in $R$. eutropha $\mathrm{H} 16$ coordinately with indigenous $\mathrm{ReSH}$ in a similar level for effective in vivo coupling reaction. For this purpose, expression of KlADH was examined by using ReSH promoter. When the transformant H16KLB4 was cultivated aerobically by hydrogenase derepressing FGN medium for $24 \mathrm{hr}$, the respective $\mathrm{ReSH}$ and KlADH activities in the soluble fraction (SF) were $3.22 \mathrm{U} / \mathrm{ml}$ and $4.64 \mathrm{U} / \mathrm{ml}$. The SF prepared from $R$. eutropha H16 cultivated in the same condition showed $\mathrm{ReSH}$ activity of $4.10 \mathrm{U} / \mathrm{ml}$ and no detectable ADH activity. Consequently, the cell suspension of H16-KLB4 


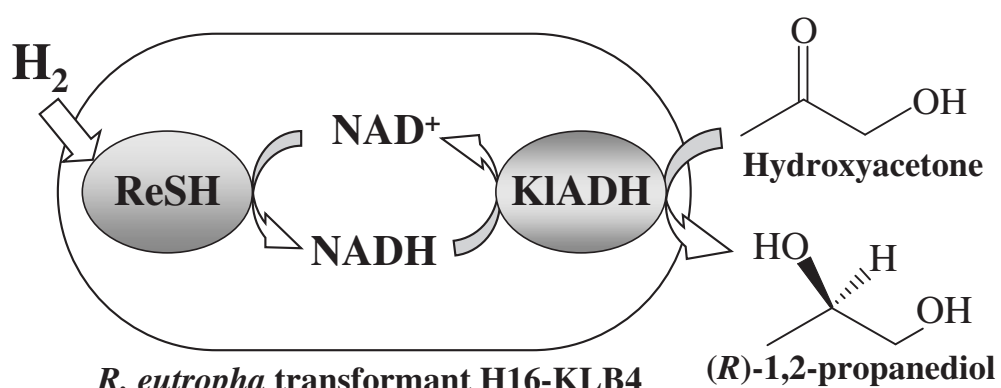

Figure 1 Hydrogen-driven asymmetric reduction of hydroxyacetone by $R$. eutropha transformant expressing alcohol dehydrogenase from $K$. lactis. The diagram shows continuous production of (R)-1,2-propanediol by in vivo coupling reaction of indigenous soluble NAD-reducing hydrogenase $(\mathrm{ReSH})$ and alcohol dehydrogenase from $\mathrm{K}$. lactis (KIADH) expressed under the control of ReSH promoter.

was subjected to $\mathrm{H}_{2}$-driven reduction of hydroxyacetone to examine $\mathrm{ReSH}-\mathrm{KlADH}$ in vivo coupling reaction.

$\mathrm{H}_{2}$-driven asymmetric reduction of hydroxyacetone by $R$. eutropha transformant expressing KIADH: in vivo coupling reaction of ReSH and KIADH

Reduction of hydroxyacetone proceeded by in vivo coupling reaction of $\mathrm{ReSH}$ and $\mathrm{KlADH}$ in $R$. eutropha H16KLB4 cells in vials (Figure 2). The SF prepared from the cell suspension used for the reaction contained $2.25 \mathrm{U} / \mathrm{ml}$ and $1.73 \mathrm{U} / \mathrm{ml}$ of $\mathrm{ReSH}$ and $\mathrm{KlADH}$ activities, respectively.

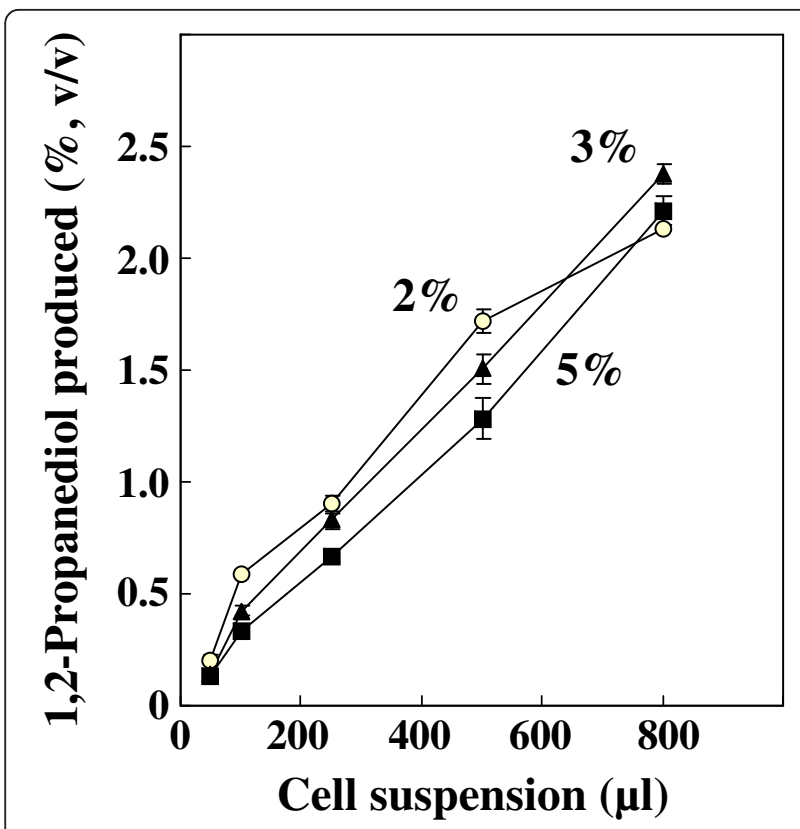

Figure 2 Hydrogen-driven production of 1,2-propanediol by R. eutropha transformant H16-KLB4 using various amount of cell suspension. The initial concentration of hydroxyacetone $(\mathrm{v} / \mathrm{V})$ in the reaction mixture was 2\% (0), 3\% (black triangle), or 5\% (black square). The SF prepared from the cell suspension (1 $\mathrm{g}$ wet cell/5 $\mathrm{ml}$ reaction buffer) used for the reaction contained $2.25 \mathrm{U} / \mathrm{ml}$ and 1.73 $\mathrm{U} / \mathrm{ml}$ of ReSH and KIADH activities, respectively. In each condition, reaction was performed in two vials.
No NADH was added to the reaction system: only indigenous cofactor was used for the reaction. The production of 1,2-propanediol was increased by increasing the cell suspension used for the reaction. When $800 \mu \mathrm{l}$ of cell suspension was used, $2 \%(\mathrm{v} / \mathrm{v})$ of hydroxyacetone was reduced completely (conversion yield; calculated as 99.1\%) and the reaction presumably stopped within $20 \mathrm{hr}$. The decrease of reaction velocity at higher initial concentration of hydroxyacetone was lowered markedly compared to in vitro enzymatic coupling reaction. When $2 \%$ $(\mathrm{v} / \mathrm{v}, 294 \mu \mathrm{mol}$ in the reaction mixture) of hydroxyacetone was subjected to the reaction using $500 \mu \mathrm{l}$ of cell suspension, for example, the concentration of 1,2-propanediol reached $1.72 \%(\mathrm{v} / \mathrm{v}, 253 \mu \mathrm{mol}$ in the reaction mixture) in $20 \mathrm{hr}$. Relative to this productivity, $88.4 \%$ and $74.4 \%$ of product were obtained even though the initial concentrations of hydroxyacetone were increased respectively to $3 \%$ and 5\%. Goldberg et al. [16] reviewed that biocatalytic ketone reduction becomes more stable by using cell catalysts compared to reactions with isolated enzymes in most cases because the enzymes are able to react in their natural environment inside the cell. Our result also showed such advantage of utilizing cell catalyst to stabilize the conversion reaction.

The fed-batch conversion of hydroxyacetone was investigated further using a jar fermenter under continuous flow of hydrogen (Figure 3). Production of 1,2-propanediol continued for long period with an almost constant rate, which reached $6.54 \%(\mathrm{v} / \mathrm{v}, 67.7 \mathrm{~g} / \mathrm{l})$ after $76 \mathrm{hr}$ reaction with average reaction velocity of $0.89 \mathrm{~g} / \mathrm{l} / \mathrm{hr}$. According to this average reaction velocity, $2 \%(\mathrm{v} / \mathrm{v}, 294 \mathrm{mmol} / \mathrm{l})$ of substrate periodically added to the reactor was converted completely in every $25.2 \mathrm{hr}$. The conversion yield of substrate supplied in total $(8 \%, \mathrm{v} / \mathrm{v})$ was calculated as $75.6 \%$ in $76 \mathrm{hr}$ reaction. The obtained average reaction velocity corresponds to $28.3 \%$ of the expected value $(3.15 \mathrm{~g} / \mathrm{l} / \mathrm{hr})$ calculated from the lower enzyme unit $(\mathrm{KlADH})$ in the SF prepared from a cell suspension used for the reaction $(\mathrm{ReSH}, 2.84 \mathrm{U} / \mathrm{ml} \mathrm{KlADH}, 1.38 \mathrm{U} / \mathrm{ml})$. 


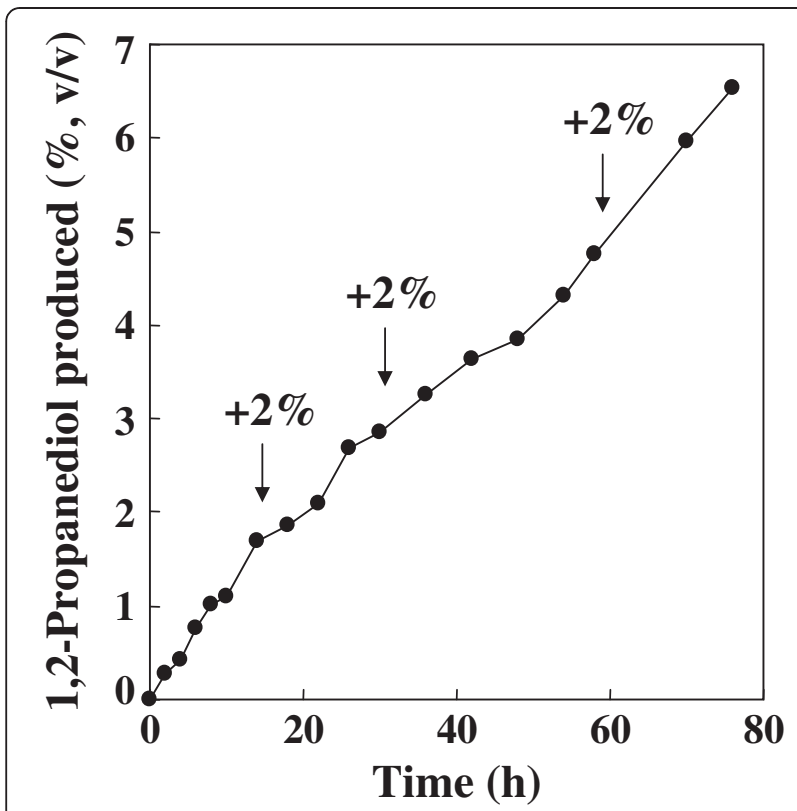

Figure 3 Hydrogen-driven fed-batch production of 1,2propanediol by $R$. eutropha transformant H16-KLB4 with a jar fermenter. The reaction started with $120 \mathrm{ml}$ of reaction mixture containing $60 \mathrm{ml}$ cell suspension ( $1 \mathrm{~g}$ wet cell/5 $\mathrm{ml}$ reaction buffer) and $2 \%(\mathrm{v} / \mathrm{v})$ hydroxyacetone. Hydroxyacetone was added periodically as indicated by arrows as the reaction proceeded. The SF prepared from the cell suspension used for the reaction contained $2.84 \mathrm{U} / \mathrm{ml}$ and $1.38 \mathrm{U} / \mathrm{ml}$ of ReSH and KIADH activities, respectively.

The $76 \mathrm{hr}$ reaction sample showed $99.8 \%$ enantiomeric excess of $(R)$-1,2-propanediol.

The reaction velocities varied depending roughly on the $\mathrm{ReSH}$ and KlADH activities present in the cells freshly cultivated for each reaction. For example, average reaction velocities of $1.08 \mathrm{~g} / \mathrm{l} / \mathrm{h}(2.77 \mathrm{U} / \mathrm{ml} \mathrm{ReSH}$ and $2.45 \mathrm{U} / \mathrm{ml} \mathrm{KlADH}$ in the cell suspension) and $0.78 \mathrm{~g} / \mathrm{l} / \mathrm{h}$ $(1.15 \mathrm{U} / \mathrm{ml} \mathrm{ReSH}$ and $1.36 \mathrm{U} / \mathrm{ml} \mathrm{KlADH}$ in the cell suspension) were obtained in the same working conditions (data not shown). However, reactions continuously proceeded almost linearly in each batch reaction, as also observed in the experiments shown by Figures 4 and 5 .

Two reports have described a $\mathrm{H}_{2}$-driven coupling reaction using $R$. eutropha cells for cofactor regeneration, but they are in vitro coupling systems and performed in an organic-aqueous two-phase system with vials. Andersson et al. [12] combined commercial horse-liver alcohol dehydrogenase and permeabilized $R$. eutropha cells for reduction of cyclohexanone to cyclohexanol. The conversion yield of $200 \mu \mathrm{mol}$ cyclohexanone in $2 \mathrm{ml}$ heptane $(0.2 \mathrm{ml}$ aqueous phase) reached $98 \%$ (9.8 $\mathrm{g} / \mathrm{l}$ product) in the presence of $1 \mu \mathrm{mol}$ NAD, but the reaction velocity decreased greatly after $24 \mathrm{hr}$. Rundbäck et al. [13] studied reduction of 2-octane to (S)-2-octanol by the combination of permeabilized cells of Gluconobacter oxydans and $R$. eutropha.

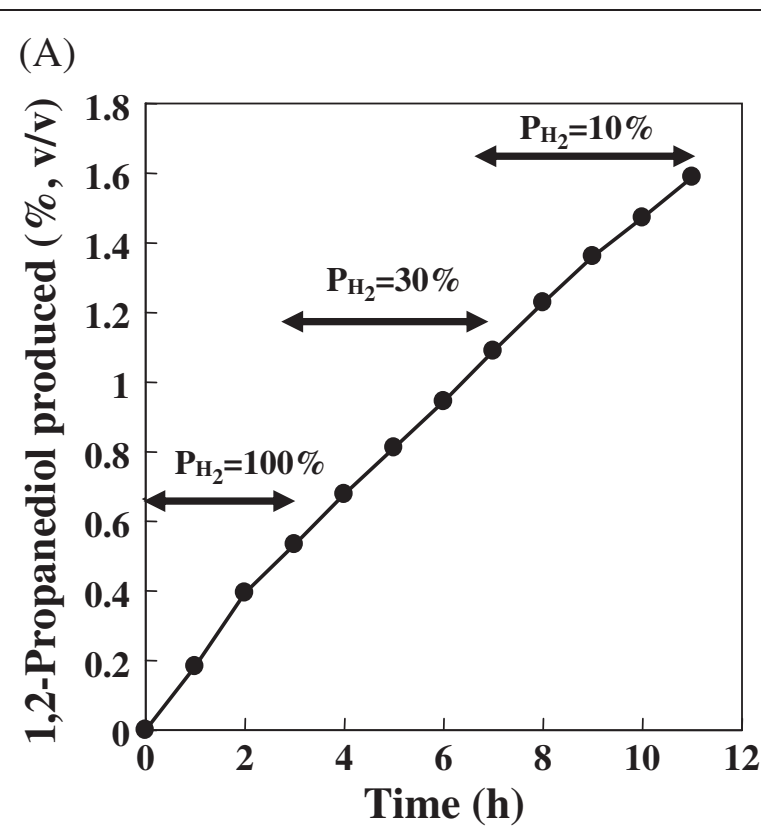

(B)

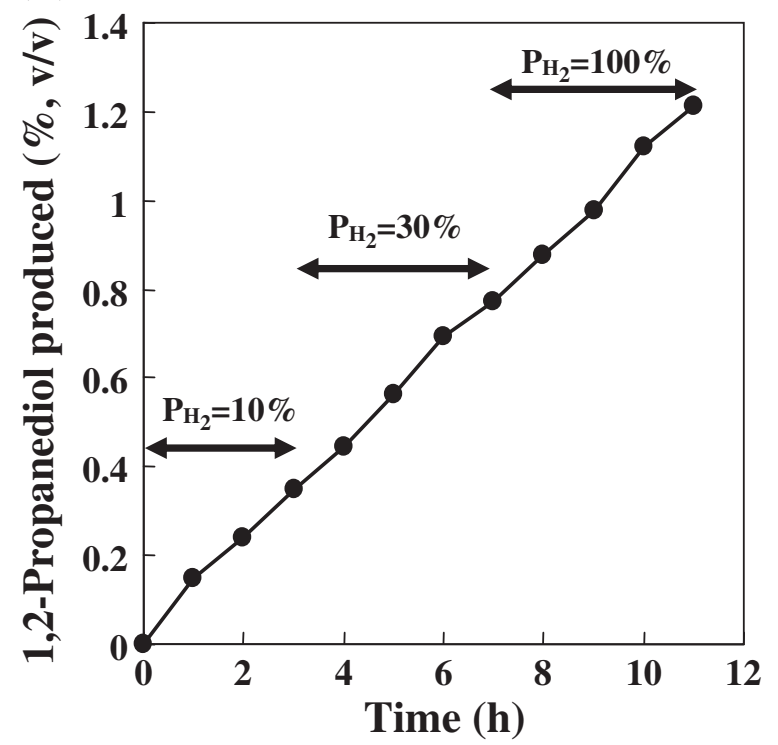

Figure 4 Influence of $\mathrm{P}_{\mathrm{H} 2}$ on the $\mathrm{H}_{2}$-driven reaction by R. eutropha transformant with a jar fermenter. The reaction mixture $(120 \mathrm{ml})$ contained $110 \mathrm{ml}$ cell suspension of H16-KLB4 (1 g wet cell/ $/ 5 \mathrm{ml}$ reaction buffer) and $2 \%(\mathrm{~V} / \mathrm{v})$ hydroxyacetone. (A) As the figure shows, the $\mathrm{P}_{\mathrm{H} 2}$ supplied to the reaction mixture decreased from $100 \%$ to $10 \%$ in a stepwise manner. The SF prepared from the cell suspension used for the reaction contained $1.90 \mathrm{U} / \mathrm{ml}$ and $2.85 \mathrm{U} / \mathrm{ml}$ of ReSH and KIADH activities, respectively. (B) As the figure shows, the $\mathrm{P}_{\mathrm{H} 2}$ supplied to the reaction mixture was increased from $10 \%$ to $100 \%$. The SF prepared from the cell suspension used for the reaction contained $1.86 \mathrm{U} / \mathrm{ml}$ and $3.61 \mathrm{U} / \mathrm{ml}$ of ReSH and KIADH activities, respectively. 


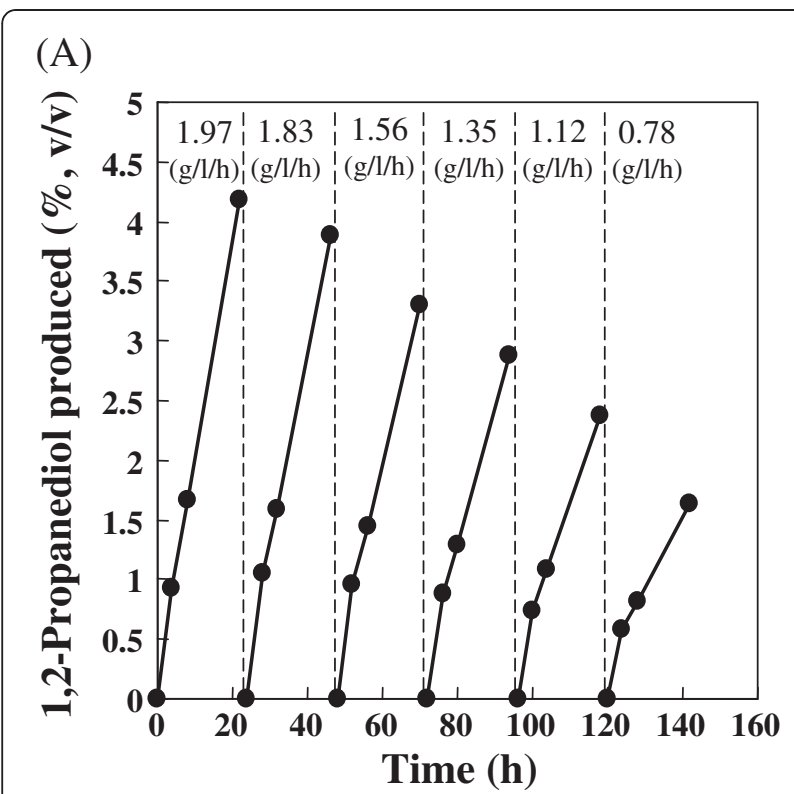

(B)

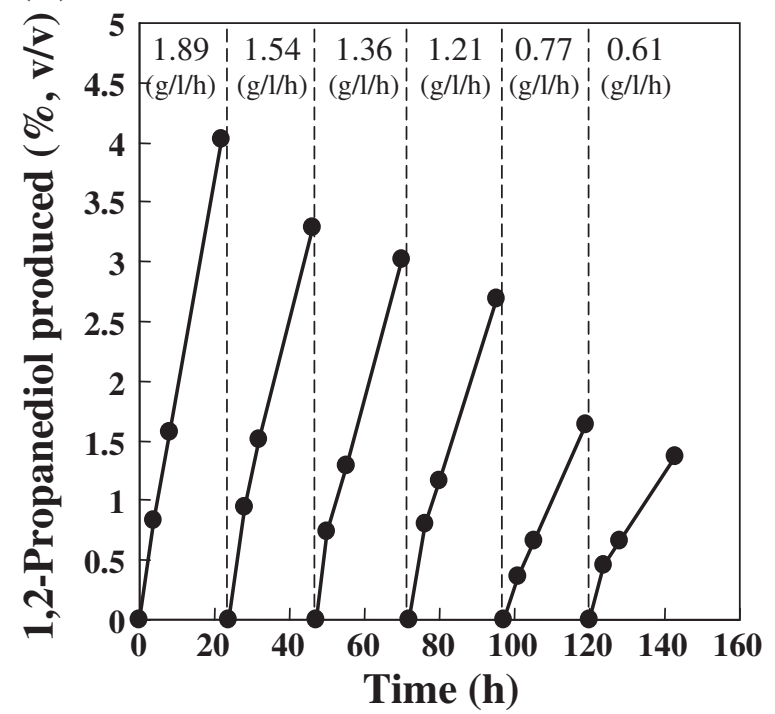

Figure 5 Repetitive batch reaction by $R$. eutropha transformant H16-KLB4 with a jar fermenter. The vertical dotted lines represent the beginning of a new batch reaction. The reaction started with $120 \mathrm{ml}$ of reaction mixture containing $110 \mathrm{ml}$ cell suspension $(1 \mathrm{~g}$ wet cell/5 $\mathrm{ml}$ reaction buffer) and $2 \%(\mathrm{v} / \mathrm{v})$ hydroxyacetone.

Hydroxyacetone was additionally supplied to the reaction mixture as the reaction proceeded in each batch reaction. Cells were harvested by centrifugation after $22-23 \mathrm{hr}$ reaction, and were re-suspended in reaction buffer to make $120 \mathrm{ml}$ of reaction mixture for the next batch reaction. The average reaction velocity of the respective batch reaction is shown in the figure. Cell harvest and re-suspension procedures were conducted anaerobically using a vinyl anaerobic chamber (Coy Laboratory Products Inc., MI, USA) (A) or were done aerobically under air (B). The SF prepared from the cell suspension used for the reaction contained $1.38 \mathrm{U} / \mathrm{ml}$ and $1.76 \mathrm{U} / \mathrm{ml}(\mathbf{A})$ and $1.75 \mathrm{U} / \mathrm{ml}$ and $1.62 \mathrm{U} / \mathrm{ml}(\mathbf{B})$ of ReSH and KIADH activities, respectively.
The conversion yield of $200 \mathrm{mM}$ substrate in $0.25 \mathrm{ml} \mathrm{n}$ dodecane ( $1 \mathrm{ml}$ aqueous phase) reached about $75 \%$ (ca. $20 \mathrm{~g} / \mathrm{l})$ in the presence of $2 \mathrm{mM}$ NAD. In reaction of hydrophobic substances, the use of a second phase of an organic solvent acts as a reservoir delivering substrate to aqueous phase. The organic phase also helps to reduce possible toxicity of substrate and/or product to biocatalysts present in aqueous phase [17]. It is intriguing to consider how the in vivo coupling system by transformant cells stabilizes such reactions of hydrophobic substrates using an organic-aqueous two-phase system.

\section{Influence of $\mathrm{P}_{\mathrm{H} 2}$ on $\mathrm{H}_{2}$-driven reaction by $R$. eutropha transformant H16-KLB4}

Influence of $\mathrm{P}_{\mathrm{H} 2}$ of the headspace gas to the $\mathrm{H}_{2}$-driven reaction was investigated in vials. The reaction mixture $(1 \mathrm{ml})$ contained $500 \mu \mathrm{l}$ of cell suspension and 3\% (v/v) hydroxyacetone. The amounts of 1,2-propanediol produced in $20 \mathrm{hr}$ reaction were almost identical between $100 \%$ and $10 \% \mathrm{P}_{\mathrm{H} 2}$ (gas mixture of $\mathrm{H}_{2}$ and $\mathrm{N}_{2}, 1 \mathrm{~atm}$ ) (data not shown). The result was confirmed further by reaction with a jar fermenter (Figure 4). The reaction velocity did not change greatly by the $\mathrm{P}_{\mathrm{H} 2}$ value of the introduced gas higher than 10\%. In Figure 4A, the reaction was initiated by supplying $100 \%$ hydrogen, and the $\mathrm{P}_{\mathrm{H} 2}$ was reduced to $30 \%$; then to $10 \%$ in a stepwise manner after several hours in each condition. The average reaction velocity during the respective condition was $1.84 \mathrm{~g} / \mathrm{l} / \mathrm{hr}\left(100 \% \mathrm{H}_{2}\right), 1.35 \mathrm{~g} / \mathrm{l} / \mathrm{hr}\left(30 \% \mathrm{P}_{\mathrm{H} 2}\right)$ and $1.24 \mathrm{~g} /$ $1 /$ hr $\left(10 \% \mathrm{P}_{\mathrm{H} 2}\right)$. When gas $\mathrm{P}_{\mathrm{H} 2}$ was increased from $10 \%$ to $100 \%$ in reverse, $1.21 \mathrm{~g} / \mathrm{l} / \mathrm{hr}\left(10 \% \mathrm{P}_{\mathrm{H} 2}\right), 1.13 \mathrm{~g} / \mathrm{l} / \mathrm{hr}$ $\left(30 \% \mathrm{P}_{\mathrm{H} 2}\right)$ and $1.17 \mathrm{~g} / \mathrm{l} / \mathrm{hr}\left(100 \% \mathrm{H}_{2}\right)$ average reaction velocities were obtained (Figure 4B). Gas mixtures of $\mathrm{P}_{\mathrm{H} 2}$ of less than $10 \%$ could not be prepared because of the range limit of the thermal mass flow meter, but it was confirmed that the presence of $10 \% \mathrm{H}_{2}$ in gas mixture was sufficient to maintain the reaction velocity equivalent to that by $100 \%$ hydrogen. The saturated $\mathrm{H}_{2}$ concentration in water phase is $68 \mu \mathrm{M}$ at $30^{\circ} \mathrm{C}$ under gas phase $(1 \mathrm{~atm})$ containing $10 \% \mathrm{P}_{\mathrm{H} 2}$. The result is consistent with the $K_{m}$ value of ReSH, which is obtained experimentally as $6.1-11.9 \mu \mathrm{M}[18,19]$.

\section{Repetitive batch reaction by $R$. eutropha transformant H16-KLB4 with a jar fermenter}

Repetitive $\mathrm{H}_{2}$-driven reaction by the transformant was investigated using a jar fermenter under continuous flow of hydrogen. The reaction was started with $2 \%(\mathrm{v} / \mathrm{v})$ of hydroxyacetone, which was added successively to the reaction mixture as the reaction proceeded. Cells were harvested by centrifugation after a batch reaction of $22-23 \mathrm{hr}$, and were subjected to the next batch reaction (Figure 5). When the procedure of cell harvest and resuspension in a fresh reaction buffer was operated anaerobically to protect 
$\mathrm{ReSH}$ from oxidative inactivation, average reaction velocities were maintained above $1 \mathrm{~g} / \mathrm{l} / \mathrm{hr}$ during five batch reactions. The product reached $189 \mathrm{~g} / \mathrm{l}$ in all by six batch runs (total net reaction time; $132 \mathrm{hr}$ ), in which the average reaction velocity obtained using the sixth batch reaction corresponded to $39.6 \%$ of the first batch (Figure 5A). Most hydrogenases are sensitive to oxygen, which causes loss of catalytic activity by oxidation of active site and/or FeS clusters under air atmosphere [20]. However, the cell activity was not greatly affected by handling in air. When cell harvest and resuspension procedures were operated under air, average reaction velocities higher than $1 \mathrm{~g} / \mathrm{l} / \mathrm{hr}$ persisted until the fourth batch reaction. The total 1,2-propanediol produced by six batch reactions reached $166 \mathrm{~g} / \mathrm{l}$ (total net reaction time; $135 \mathrm{hr}$ ), in which $32.3 \%$ of average reaction velocity relative to that of the first batch was retained in the sixth batch reaction (Figure $5 \mathrm{~B}$ ). The results are attributable to the high oxygen tolerance of $\mathrm{ReSH}[7,8]$. In addition, there will be an advantage of in vivo coupling system in maintaining lower oxygen level inside the cell.

\section{Conclusions}

The coupling reaction of $\mathrm{ReSH}$ and $\mathrm{KlADH}$ continued in the presence of hydrogen in both in vitro and in vivo systems. This report of a hydrogen-driven bioconversion by in vivo coupling system is the first describing the use of $R$. eutropha transformant expressing KlADH (Figure 1). The in vivo coupling reaction proceeded continuously only by cell suspension, which did not require exogenous addition of a cofactor. The concentration of $(R)-1,2$-propanediol reached $67.7 \mathrm{~g} / \mathrm{l}$ by periodical addition of hydroxyacetone without a marked decrease of reaction velocity. Reuse of transformant cells became available by in vivo coupling reaction. Moreover, the presence of $10 \% \mathrm{P}_{\mathrm{H} 2}$ retained a reaction velocity equivalent to that by $100 \%$ hydrogen, indicating the availability of crude hydrogen gas from various sources. These results suggest a hopeful perspective of hydrogen-driven bioprocesses using in vivo coupling system to achieve industrial green innovation.

\section{Methods}

\section{Bacterial strains, plasmids, and cultivations}

Strains and plasmids used for this study are presented in Table 1. Ralstonia eutropha H16 was used as a host for expression of KlADH [15]. E. coli XL-1 Blue (Stratagene Cloning Systems Inc., Amsterdam, Netherlands) was used as a host in standard cloning procedure, and E. coli S17-1 [21] was used in conjugative plasmid transfer. Strains of $R$. eutropha were cultivated heterotrophically in modified LB medium, FN medium, or FGN medium at $30{ }^{\circ} \mathrm{C}[22]$. FN medium ( $\left.\mathrm{pH} 7.0\right)$ contained the following components per liter: fructose $4 \mathrm{~g} ; \mathrm{Na}_{2} \mathrm{HPO}_{4}$. $12 \mathrm{H}_{2} \mathrm{O} 9 \mathrm{~g} ; \mathrm{KH}_{2} \mathrm{PO}_{4} 1.5 \mathrm{~g} ; \mathrm{NH}_{4} \mathrm{Cl} 2 \mathrm{~g} ; \mathrm{MgSO}_{4} \cdot 7 \mathrm{H}_{2} \mathrm{O}$
0.2 g; $\mathrm{CaCl}_{2} \cdot 2 \mathrm{H}_{2} \mathrm{O} 10 \mathrm{mg} ; \mathrm{FeCl}_{3} \cdot 6 \mathrm{H}_{2} \mathrm{O} 5 \mathrm{mg} ; \mathrm{NiCl}_{2}$. $6 \mathrm{H}_{2} \mathrm{O} 19 \mathrm{mg}$. FGN medium ( $\mathrm{pH} 7.0$ ) contained the following components per liter: fructose $2 \mathrm{~g}$; glycerol $2 \mathrm{ml}$; $\mathrm{Na}_{2} \mathrm{HPO}_{4} \cdot 12 \mathrm{H}_{2} \mathrm{O} 9$ g; $\mathrm{KH}_{2} \mathrm{PO}_{4} 1.5$ g; $\mathrm{NH}_{4} \mathrm{Cl} 2$ g; $\mathrm{MgSO}_{4}$. $7 \mathrm{H}_{2} \mathrm{O} 0.2 \mathrm{~g} ; \mathrm{CaCl}_{2} \cdot 2 \mathrm{H}_{2} \mathrm{O} 10 \mathrm{mg} ; \mathrm{FeCl}_{3} \cdot 6 \mathrm{H}_{2} \mathrm{O} 5 \mathrm{mg}$; $\mathrm{NiCl}_{2} \cdot 6 \mathrm{H}_{2} \mathrm{O} 190 \mathrm{mg}$. For preparation of hydrogenase derepressed cells, cultivation was done aerobically in FGN medium for 24 hr [22] after pre-cultivation using modified LB medium. Strains of $E$. coli were grown aerobically in LB medium at $37^{\circ} \mathrm{C}$ [23]. Solid medium contained $1.5 \%$ agar (w/v). Antibiotics were supplemented as follows when necessary: $15 \mu \mathrm{g} / \mathrm{ml}$ of tetracycline, $100 \mu \mathrm{g} / \mathrm{ml}$ of ampicillin. E. coli HB101 (Takara Bio Inc., Tokyo, Japan) transformed by pSE-KLB2 [15] which possesses KlADH gene in pSE420 (Invitrogen Corp., CA, USA) was used for preparation of the SF containing KlADH. The transformant was cultivated in LB medium containing ampicillin and IPTG was added to the culture to be $0.1 \mathrm{mM}$ when O.D. at $660 \mathrm{~nm}$ reached 0.6-0.7. Cells were cultivated another $4 \mathrm{hr}$ and harvested for preparation of the SF.

\section{Construction of KIADH expression vector and transformation of $R$. eutropha $\mathrm{H} 16$}

Standard DNA techniques were used for DNA manipulation [24]. The plasmid pSE-KLB2 containing the complete 1,155-bp KlADH gene [15] was used as a PCR template to introduce Nde I site at the initiation codon ATG and Xba I site at the end of the amplified PCR fragment. The following oligonucleotides were used as primers. Therein, designed restriction sites are underlined and mismatched nucleotides to the original sequence are shown in lower case letters: $5^{\prime}$-GAATT CTcatATGCGTGCATTAGCTTATTTCGG- $3^{\prime}$ and $5^{\prime}$ AACAGTTCTAGAACCCTCTTTGACAAGC-3'. The amplified 401-bp fragment was phosphorylated using a Mighty cloning reagent set (Takara Bio Inc.) and cloned to Eco RV site of pBluescript KS (+) (Stratagene Cloning Systems Inc.) to confirm the sequence. A thermosequenase primer cycle sequencing kit (GE Healthcare UK Ltd., Buckinghamshire, England) and DNA sequence LIC-4200S (Li-Cor Inc., Lincoln, NE, USA) were used for sequencing. The PCR fragment of the obtained recombinant plasmid pBlueKLB3F, whose authenticity of the sequence was confirmed, was digested by Nde I and Xba I and was ligated to the corresponding site of the $\mathrm{pCH} 591$ [25]. The resulting plasmid pCH-KLB2 contained the initial 385-bp fragment of $\mathrm{KlADH}$ gene at the downstream of $\mathrm{ReSH}$ promoter. The plasmid was digested by $P f l \mathrm{MI}$ and $X b a \mathrm{I}$, into which the 1,005-bp Pfl MI-Xba I fragment from pSEKLB2 was introduced. The resulting plasmid $\mathrm{pCH}-$ KLB3 contained a complete set of the $\mathrm{ReSH}$ promoter and KlADH gene. The Eco RV-Sna BI fragment from pCH-KLB3 containing the set was introduced to Swa I 
Table 1 Bacterial strains and plasmids used for this study

\begin{tabular}{|c|c|c|}
\hline Strain or plasmid & Relevant characteristic(s) & Source or reference \\
\hline \multicolumn{3}{|l|}{ Strains } \\
\hline \multicolumn{3}{|l|}{ R. eutropha } \\
\hline $\mathrm{H} 16$ & Wild type & DSM 428, ATCC 17699 \\
\hline H16-KLB4 & H16 transformed by pEDY-KLB4 & This study \\
\hline \multicolumn{3}{|l|}{ E. coli } \\
\hline$X L-1$ Blue & recA1 endA1 gyrA96 thi-1 hsdR17 supE44 relA1 lac [F' proAB lacla lacZDM15 Tn10 (TC')] & Stratagene Cloning Systems Inc. \\
\hline S17-1 & $\mathrm{Tra}^{+}$recA pro thi hsdR, chr::RP4-2 & 21 \\
\hline HB101 & $\begin{array}{l}\left.\mathrm{F}^{-} \text {, leuB6 } \Delta \text { (gpt-proA)62 recA13 thi-1 ara-14 lacY1 galK2 xyl-5 mtl-1 rpsL20(Str }{ }^{+}\right) \text {supE44 } \\
\Delta(m c r C-m r r)\end{array}$ & Takara Bio Inc. \\
\hline \multicolumn{3}{|l|}{ Plasmids } \\
\hline pBluescript KS (+) & Apr lacZ', T7 gene 10 promoter, f1 ori & Stratagene Cloning Systems Inc. \\
\hline pSE-KLB2 & 1,183-bp EcoRI-AfII fragment containing the complete KIADH gene in pSE420 & 15 \\
\hline pCH591 & 260-bp Hindlll-Ndel fragment containing the ReSH promoter in Litmus 29 & 25 \\
\hline pEDY309 & RK2 ori, $\mathrm{TC}^{r}, \mathrm{Mob}^{+}$ & 25 \\
\hline pBlueKLB3F & 401-bp PCR fragment containing a part of KIADH gene in EcoRV digested pBluescript KS (+) & This study \\
\hline $\mathrm{pCH}-\mathrm{KLB} 2$ & 385-bp Ndel-Xbal fragment from pBlueKLB3F in pCH591 downstream of ReSH promoter & This study \\
\hline $\mathrm{pCH}-\mathrm{KLB} 3$ & 1,005-bp PfIMI-Xbal fragment from pSE-KLB2 in pCH-KLB2 & This study \\
\hline pEDY-KLB4 & $\begin{array}{l}\text { EcoRV-SnaBl fragment containing a complete set of the ReSH promoter and KIADH gene } \\
\text { from } \mathrm{pCH}-\mathrm{KLB} 3 \text { in Swal digested pEDY309 }\end{array}$ & This study \\
\hline
\end{tabular}

site of pEDY 309 [25]. The resulting plasmid pEDYKLB4 was transformed into E. coli S17-1 and transferred to $R$. eutropha $\mathrm{H} 16$ by spot mating, by which $R$. eutropha transformant H16-KLB4 was obtained. Purification of the PCR amplified fragment and extraction of DNA fragment from the gel strip were done using gel extraction kit (QIA quick; Qiagen GmbH, Hilden, Germany). The plasmids pCH591 and pEDY309 were kindly donated by Dr. B. Friedrich and Dr. O. Lenz (Humboldt Universität zu Berlin, Germany).

\section{Preparation of SF}

The cells were washed using $50 \mathrm{mM}$ potassium phosphate (KP) buffer $(\mathrm{pH} 7.0)$ and centrifuged at $7,000 \times g$ for $20 \mathrm{~min}$ at $4^{\circ} \mathrm{C}$. The washed cells were suspended homogeneously in the same buffer to be $1 \mathrm{~g}$ wet cell $/ 5 \mathrm{ml}$ and were broken twice (50 W, 5 min, Sonifier 250; Branson Ultrasonics Corp., CT, USA). Cell debris and unbroken cells were removed by centrifugation at $7,000 \times g$ for $30 \mathrm{~min}$ at $4^{\circ} \mathrm{C}$. Membranes in the cell-free extract were removed by ultracentrifugation at $100,000 \times g$ for $1 \mathrm{hr}$ at $4^{\circ} \mathrm{C}$. The supernatant was used as SF.

\section{Enzyme assays}

NAD-reducing hydrogenase activity was determined spectrophotometrically at $30^{\circ} \mathrm{C}$ by following the $\mathrm{H}_{2}$ dependent reduction of NAD as an electron acceptor using glass cuvettes sealed with a rubber stopper and an aluminum cap [26]. The assay mixture contained $2 \mathrm{mM}$ NAD in $50 \mathrm{mM} \mathrm{KP}$ buffer (pH 7.0). NAD-reducing activity of KlADH was similarly measured spectrophotometrically at $30^{\circ} \mathrm{C}$ in the presence of $20 \mathrm{mM}(R)-1,2-$ propanediol and $2.5 \mathrm{mM}$ NAD in $50 \mathrm{mM}$ KP buffer ( $\mathrm{pH}$ 7.0). One unit of activity was defined as the amount of enzyme that reduced $1 \mu \mathrm{mol}$ of NAD in a minute. The amount of reduced NAD was determined by the increase of absorbance at $340 \mathrm{~nm}\left(\varepsilon_{340 \mathrm{~nm}}=6.22 \mathrm{mM}^{-1} \mathrm{~cm}^{-1}\right)$. Protein concentrations were estimated routinely [27] using established procedures of Bio-Rad Protein Assay (Bio-Rad Laboratories Inc., CA, USA).

\section{$\mathrm{H}_{2}$-driven reduction of hydroxyacetone by in vitro enzymatic coupling of ReSH and KIADH}

SFs containing ReSH and KlADH were prepared respectively from $R$. eutropha $\mathrm{H} 16$ and $E$. coli $\mathrm{HB} 101$ possessing pSE-KLB2 cells as described above. They were added to give $0.2 \mathrm{U} / \mathrm{ml}$ of each enzyme to the reaction mixture containing $1 \mathrm{mM} \mathrm{NAD}$ and $2 \%$ or $3 \%(\mathrm{v} / \mathrm{v})$ of hydroxyacetone in $50 \mathrm{mM} \mathrm{KP}$ buffer ( $\mathrm{pH}$ 7.0). The reaction was performed in a $10 \mathrm{ml}$ vial containing $1 \mathrm{ml}$ of reaction mixture, which was sealed with a rubber stopper and an aluminum cap, at $30^{\circ} \mathrm{C}$ for $20 \mathrm{hr}$ under shaking at $130 \mathrm{rpm}$. The reaction was initiated by adding hydroxyacetone with a syringe after hydrogen was filled into the vial head space.

\section{$\mathrm{H}_{2}$-driven reduction of hydroxyacetone by $R$. eutropha transformant expressing KIADH: in vivo coupling reaction of ReSH and KIADH}

The cell suspension of $R$. eutropha H16-KLB4, which was cultivated under hydrogenase derepressing condition, was 
prepared to be $1 \mathrm{~g}$ of wet cell per $5 \mathrm{ml}$ reaction buffer (50 mM KP buffer, pH 7.0) and subjected as microbial catalyst. $\mathrm{ReSH}$ and $\mathrm{KlADH}$ activities present in the cell suspension were measured by preparing SF as described above. The reaction with $10-\mathrm{ml}$ vials was done as in vitro enzymatic coupling reaction under hydrogen atmosphere at $30^{\circ} \mathrm{C}$ for $20 \mathrm{hr}$. Gas mixtures of $\mathrm{H}_{2}$ and $\mathrm{N}_{2}$ (1 atm) were prepared using thermal mass flow meters (Emerson Japan, Ltd., Tokyo, Japan) when the influence of headspace $\mathrm{P}_{\mathrm{H} 2}$ on the reaction was investigated. The reaction mixture $(1 \mathrm{ml})$ contained $50-800 \mu \mathrm{l}$ cell suspension and $2-5 \%$ (v/v) of hydroxyacetone. The reaction with a $250 \mathrm{ml}$ jar fermenter (BMJ-25; Able \& Biott Co., Ltd., Tokyo, Japan) was performed at $30^{\circ} \mathrm{C}$ under agitation at $1,000 \mathrm{rpm}$. Hydrogen gas was supplied to the reaction mixture with a thermal mass flow meter (Emerson Japan, Ltd.) at a flow rate of $250 \mathrm{ml} / \mathrm{min}$. Gas mixtures of $\mathrm{H}_{2}$ and $\mathrm{N}_{2}$ (1 atm) were supplied at a total flow rate of $250 \mathrm{ml} / \mathrm{min}$ when influence of $\mathrm{P}_{\mathrm{H} 2}$ was investigated. The reaction mixture $(120 \mathrm{ml})$ contained $60 \mathrm{ml}$ or $110 \mathrm{ml}$ cell suspension and $2 \%(\mathrm{v} / \mathrm{v})$ of hydroxyacetone at the beginning of reaction. When the reaction was continued to reach higher product concentration, hydroxyacetone $(2 \%, \mathrm{v} / \mathrm{v})$ was added periodically to the reaction mixture as the reaction proceeded. The reaction $\mathrm{pH}$ was controlled using a $\mathrm{pH}$ controller (FC-2000; Tokyo Rikakikai Co., Ltd., Tokyo, Japan).

\section{Measurement of 1,2-propanediol and chirality analysis}

The reaction mixtures of in vitro enzymatic reaction were taken to sampling tubes, which were boiled for 5 min to stop the reaction and centrifuged. The supernatants were subjected to quantification of 1,2-propanediol using a gas chromatograph (GC-14B; Shimadzu Corp., Kyoto, Japan) equipped with a column $(2.1 \mathrm{~m} \times 3.2 \mathrm{~mm}$ internal diameter) packed with 5\% Thermon-3000 (Chromosorb W 80/100 AW-DMCS; Shimadzu GLC Ltd., Tokyo, Japan) and a flame ionization detector. The column temperature was $150^{\circ} \mathrm{C}$. The samples of in vivo coupling reaction were centrifuged to remove $R$. eutropha H16-KLB4 cells, and the supernatants were boiled for $5 \mathrm{~min}$ and centrifuged again. The supernatants were subjected to gas chromatography as described above. Optical purity of 1,2-propanediol produced was analyzed using a high performance liquid chromatograph (L-6320; Hitachi, Ltd., Tokyo, Japan) equipped with an OD-H column $(25 \mathrm{~cm} \times 4.6 \mathrm{~mm}$ internal diameter, Chiralcel; Daicel Corp., Tokyo, Japan) at $40^{\circ} \mathrm{C}$. Solvent consisting of $n$-hexane:2-propanol (4:1) was used as mobile phase at a flow rate of $1.0 \mathrm{ml} / \mathrm{min}$. Detection was done at $254 \mathrm{~nm}$. The sample prepared for GC analysis containing ca. $25 \mu \mathrm{l}$ of 1,2-propanediol was taken to a test tube and dissolved in ethyl acetate after evaporation of the water phase. The solvent was evaporated after filtration with a $0.45 \mu \mathrm{m}$ filter (Millex LH; Merck KG, Darmstadt,
Germany). Then the remaining sample was dissolved in $25 \mu \mathrm{l}$ of phenylisocyanate and was left to stand for $30 \mathrm{~min}$ at $50^{\circ} \mathrm{C}$. Ethanol $(25 \mu \mathrm{l})$ was added to the sample and incubated for $10 \mathrm{~min}$ at $50^{\circ} \mathrm{C}$. Solvent of the sample was exchanged to the HPLC solvent by evaporation, and was subsequently subjected to HPLC after filtration (Millex LH; Merck KG).

\section{Competing interests}

The authors declare that they have no competing interests.

\section{Authors' contributions}

$\mathrm{HN}$ designed research with the help of HY, AM (gene manipulation and activity measurement of KIADH, GC and HPLC analysis of the product), MI, YI (hydrogen-driven reactions). TO carried out genetic experiments. TO and KO performed hydrogen-driven reactions and analytical experiments. HN supervised experiment and wrote the paper. All authors contributed to improve the manuscript. The final version of the manuscript has been approved by all authors

\section{Acknowledgements}

We are grateful to Dr. Bärbel Friedrich and Dr. Oliver Lenz of Institut für Biologie, Humboldt Universität zu Berlin, Germany for kind donation of pCH591 and pEDY309, and helpful information for handling of these plasmids. This study was conducted as a part of the Project for Development of a Technological Infrastructure for Industrial Bioprocesses on R\&D of New Industrial Science and Technology Frontiers by the Ministry of Economy, Trade and Industry (METI), and entrusted by the New Energy and Industrial Technology Development Organization (NEDO).

\section{Author details}

'Department of Bioresource Science, College of Agriculture, Ibaraki University, 3-21-1 Chu-ou, Ami-machi, Inashiki-gun, Ibaraki 300-0393, Japan. ${ }^{2}$ Green Product Development Center, R\&D Management, Daicel Corporation, 1-1 Shinko-cho, Myoko, Niigata 944-8550, Japan. ${ }^{3}$ Department of Biotechnology, Graduate School of Agricultural and Life Sciences, The University of Tokyo, 1-1-1 Yayoi, Bunkyo-ku, Tokyo 113-8657, Japan.

Received: 24 August 2012 Accepted: 6 January 2013

Published: 10 January 2013

\section{References}

1. Kataoka M, Kita K, Wada M, Yasohara Y, Hasegawa J, Shimizu S: Novel bioreduction system for the production of chiral alcohols. Appl Microbiol Biotechnol 2003, 62:437-445.

2. Kroutil W, Mang $H$, Edegger $K$, Faber $K$ : Recent advances in the biocatalytic reduction of ketones and oxidation of sec-alcohols. Curr Opin Chem Biol 2004, 8:120-126.

3. Chenault HK, Whitesides GM: Regeneration of nicotinamide cofactors for use in organic synthesis. Appl Biochem Biotechnol 1987, 14:147-197.

4. Liu W, Wang P: Cofactor regeneration for sustainable enzymatic biosynthesis. Biotechnol Adv 2007, 25:369-384.

5. van der Donk WA, Zhao H: Recent developments in pyridine nucleotide regeneration. Curr Opin Biotech 2003, 14:421-426.

6. Vignais PM, Billoud B: Occurrence, classification, and biological function of hydrogenases: an overview. Chem Rev 2007, 107:4206-4272.

7. Horch M, Lauterbach L, Lenz $\mathrm{O}$, Hildebrandt $\mathrm{P}$, Zebger I: NAD(H)-coupled hydrogen cycling - structure-function relationships of bidirectional [NiFe] hydrogenases. FEBS Lett 2011, 586:545-556.

8. Ratzka J, Lauterbach L, Lenz O, Ansorge-Shumacher MB: Systematic evaluation of the dihydrogen-oxidizing and $\mathrm{NAD}^{+}$-reducing soluble hydrogenase from Ralstonia eutropha $\mathrm{H} 16$ as a cofactor regeneration catalyst. Biocat Biotrans 2011, 29:246-252.

9. Otsuka K, Aono S, Okura I: Regeneration of NAD and ketone hydrogenation by hydrogen with the combination of hydrogenase and alcohol dehydrogenase. J Mol Catal 1989, 51:35-39.

10. Hasumi F, Miyamoto Y, Okura I: Synthesis of glutamate by reductive amination of 2-oxoglutarate with the combination of hydrogenase and glutamate dehydrogenase. Appl Biochem Biotechnol 1995, 55:1-4. 
11. Takeuchi M, Okura I, Hasumi F: Regeneration of NADH and hydrogenation of dihydroxyacetone by hydrogen with the combination of hydrogenase and glycerol dehydrogenase. J Mol Catal 1991, 68:121-123.

12. Andersson M, Holmberg H, Adlercreutz P: Evaluation of Alcaligenes eutrophus cells as an NADH regenerating catalyst in organic-aqueous two-phase system. Biotech Bioeng 1998, 57:79-86.

13. Rundbäck F, Fidanoska M, Adlercreutz P: Coupling of permeabilized cells of Gluconobacter oxydans and Ralstonia eutropha for asymmetric ketone reduction using $\mathrm{H}_{2}$ as reductant. J Biotech 2012, 157:154-158.

14. Mertens R, Greiner $L$, van den Ban ECD, Haaker HBCM, Liese A: Practical application of hydrogenase I from Pyrococcus furiosus for NADPH generation and regeneration. J Mol Catal B 2003, 24-25:39-52. Enzymatic

15. Yamamoto H, Kimoto K: JP patent. 2002-345479. Tokyo: Japan Patent Office; 2002 (to Daicel Corp.).

16. Goldberg K, Schroer K, Lütz S, Liese A: Biocatalytic ketone reduction-a powerful tool for the production of chiral alcohols-part II: whole-cell reductions. Appl Microbiol Biotechnol 2007, 76:249-255.

17. Prpich GP, Daugulis AJ: Solvent selection for enhanced bioproduction of 3-methylcatecol in a two-phase partitioning bioreactor. Biotechnol Bioeng 2007, 97:536-543.

18. Keefe RG, Axley MJ, Harabin AL: Kinetic mechanism studies of the soluble hydrogenase from Alcaligenes eutrophus H16. Arch Biochem Biophys 1995, 317:449-456.

19. Ludwig M, Cracknell JA, Vincent KA, Armstrong FA, Lenz O: Oxygentolerant $\mathrm{H}_{2}$ Oxidation by Membrane-bound [NiFe] Hydrogenases of Ralstonia species coping with low level $\mathrm{H}_{2}$ in air. J Biol Chem 2009, 284:465-477.

20. Fontecilla-Camps JC, Volbeda A, Cavazza C, Nicolet Y: Structure/function relationships of [NiFe]- and [FeFe]-hydrogenases. Chem Rev 2007, 107:4273-4303.

21. Simon R, Priefer U, Pühler A: A broad host range mobilization system for in vitro genetic engineering: transposon mutagenesis in gram-negative bacteria. Bio/Technology 1983, 1:784-791.

22. Eberz $G$, Friedrich $B$ : Three trans-acting regulatory functions control hydrogenase synthesis in Alcaligenes eutrophus. J Bacteriol 1981, 173:1845-1854.

23. Miller JH: Experiments in molecular genetics. New York: Cold Spring Harbor Laboratory, Cold Spring Harbor; 1972.

24. Sambrook J, Fritsch EF, Maniatis T: Molecular cloning: a laboratory manual. New York: Cold Spring Harbor Laboratory: Cold Spring Harbor; 1989.

25. Kleihues L, Lenz O, Bernhard M, Buhrke T, Friedrich B: The $\mathrm{H}_{2}$ sensor of Ralstonia eutropha is a member of the subclass of regulatory [NiFe] hydrogenases. J Bacteriol 2000, 182:2716-2724.

26. Yoon KS, Fukuda K, Fujisawa K, Nishihara H: Purification and characterization of a highly thermostable, oxygen-resistant, respiratory [NiFe]-hydrogenase from a marine, aerobic hydrogen-oxidizing bacterium Hydrogenovibrio marinus. Int J Hydrogen Energ 2011, 36:7081-7088.

27. Bradford MM: A rapid and sensitive method for the quantitation of microgram quantities of protein utilizing the principle of protein-dye binding. Anal Biochem 1976, 72:248-254.

doi:10.1186/1475-2859-12-2

Cite this article as: Oda et al:: Hydrogen-driven asymmetric reduction of hydroxyacetone to $(R)$-1,2-propanediol by Ralstonia eutropha transformant expressing alcohol dehydrogenase from Kluyveromyces lactis. Microbial Cell Factories 2013 12:2.

\section{Submit your next manuscript to BioMed Central and take full advantage of:}

- Convenient online submission

- Thorough peer review

- No space constraints or color figure charges

- Immediate publication on acceptance

- Inclusion in PubMed, CAS, Scopus and Google Scholar

- Research which is freely available for redistribution

Submit your manuscript at www.biomedcentral.com/submit 